\title{
The relationship of cigarette smoking in Japan to lung cancer, COPD, ischemic heart disease and stroke: A systematic review
}

\section{[version 1; peer review: 2 approved]}

\author{
Peter N. Lee (D1), Barbara A. Forey², Alison J. Thornton³, Katharine J. Coombs ${ }^{1}$ \\ ${ }^{1}$ P.N. Lee Statistics and Computing Ltd., Sutton, SM2 5DA, UK \\ ${ }^{2}$ Independent Consultant in Statistics, Dartmouth, TQ6 9HB, UK \\ ${ }^{3}$ Independent Consultant in Statistics, Okehampton, EX20 1SG, UK
}

\begin{tabular}{l}
\hline V1 First published: 19 Feb 2018, 7:204 \\
https://doi.org/10.12688/f1000research.14002.1 \\
Latest published: 19 Feb 2018, 7:204 \\
https://doi.org/10.12688/f1000research.14002.1 \\
\hline
\end{tabular}

\section{Abstract}

Background: To present up-to-date meta-analyses of evidence from Japan relating smoking to major smoking-related diseases.

Methods: We restricted attention to lung cancer, chronic obstructive pulmonary disease (COPD), ischemic heart disease (IHD) and stroke, considering relative risks (RRs) for current and ex-smokers relative to never smokers. Evidence by amount smoked and time quit was also considered. For IHD and stroke only, studies had to provide ageadjusted RRs, with age-specific results considered. For each disease we extended earlier published databases to include more recent studies. Meta-analyses were conducted, with random-effects RRs and tests of heterogeneity presented.

Results: Of 40 studies, 26 reported results for lung cancer and 7 to 9 for each other disease. For current smoking, RRs (95\%CIs) were lung cancer 3.59 (3.25-3.96), COPD 3.57 (2.72-4.70), IHD 2.21 (1.96-2.50) and stroke 1.40 (1.25-1.57). Ex-smoking RRs were lower. Data for lung cancer and IHD showed a clear tendency for RRs to rise with increasing amount smoked and decrease with increasing time quit. Dose-response data were unavailable for COPD and unclear for stroke, where the association was weaker.

Conclusions: Compared to studies in other Asian and Western countries, current smoking RRs were quite similar for IHD and stroke. The comparison is not clear for COPD, where the Japanese data, mainly from cross-sectional studies, is limited. For lung cancer, the RRs are similar to those in other Asian countries, but substantially lower than in Western countries. Explanations for this are unclear, but less accurate reporting of smoking by Japanese may contribute to the difference.

\section{Keywords}

Smoking, lung cancer, COPD, heart disease, stroke

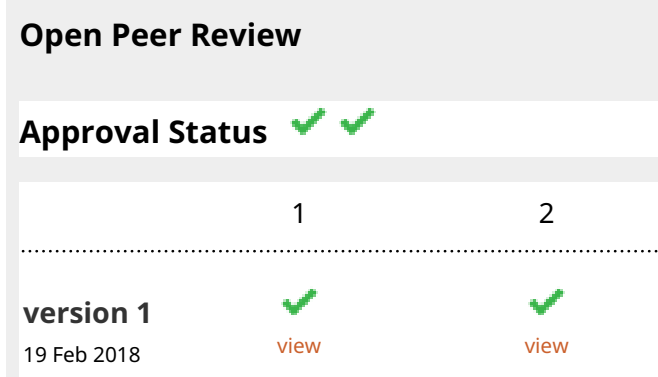

1. Joshua E. Muscat, Penn State Health Milton

S. Hershey Medical Center, Hershey, USA

2. Wolf-Dieter Heller, Karlsruhe Institute of

Technology, Karlsruhe, Germany

Any reports and responses or comments on the article can be found at the end of the article. 
Corresponding author: Peter N. Lee (PeterLee@pnlee.co.uk)

Author roles: Lee PN: Conceptualization, Data Curation, Formal Analysis, Funding Acquisition, Investigation, Methodology, Project Administration, Supervision, Validation, Writing - Original Draft Preparation, Writing - Review \& Editing; Forey BA: Formal Analysis, Methodology, Writing - Original Draft Preparation, Writing - Review \& Editing; Thornton AJ: Data Curation, Formal Analysis, Writing Review \& Editing; Coombs KJ: Data Curation, Formal Analysis, Validation, Writing - Review \& Editing

Competing interests: P N Lee Statistics and Computing Ltd, for whom PNL and KJC are directors, and BAF and AJT are consultants, have for many years carried out work for many different tobacco companies and organizations, including Philip Morris International, the sponsors of this study. The work described here has been carried out independently of the sponsors.

Grant information: Funding was provided by Philip Morris International. The only role they had in the design of the study and collection, analysis, and interpretation of data was to suggest that the review should be conducted and to provide a brief comment on a near final draft of the paper, suggesting only that we refer to our recent publication on indirectly estimated lung cancer rates by smoking status, reference 61 of the submitted paper.

Copyright: (c) 2018 Lee PN et al. This is an open access article distributed under the terms of the Creative Commons Attribution License, which permits unrestricted use, distribution, and reproduction in any medium, provided the original work is properly cited.

How to cite this article: Lee PN, Forey BA, Thornton AJ and Coombs KJ. The relationship of cigarette smoking in Japan to lung cancer, COPD, ischemic heart disease and stroke: A systematic review [version 1; peer review: 2 approved] F1000Research 2018, 7 :204 https://doi.org/10.12688/f1000research.14002.1

First published: 19 Feb 2018, 7:204 https://doi.org/10.12688/f1000research.14002.1 


\section{Introduction}

It is well established that the relative risk (RR) of lung cancer from smoking is lower in Japan than in Western populations ${ }^{1-5}$. However, studies of smoking and lung cancer in Japan have proliferated in recent years, and there have been no metaanalyses in the last 10 years, except for a review of prospective studies reported up to $2008^{6}$. While that review also considered other smoking-related diseases, there have been no other recent comprehensive meta-analyses of the relationship of smoking to chronic obstructive lung disease (COPD) or cardiovascular disease (CVD), based on studies in Japan.

Here we summarize results of Japanese studies relating smoking to lung cancer, COPD, ischaemic (or coronary) heart disease (IHD) and stroke, limiting attention to comparison with never smokers, and considering estimates for current smokers, overall and by amount smoked, and for ex-smokers, overall and by time quit. As we earlier published comprehensive reviews of the evidence for lung cancer ${ }^{4}$ and $\mathrm{COPD}^{7}$ we extend our metaanalyses to include later papers. For IHD and stroke we extend meta-analyses based on studies published from $1990^{8}$, not attempting to include earlier publications.

Apart from presenting the meta-analysis results, we also briefly compare and contrast the results for Japan with those for other regions, commenting on possible reasons for differences seen.

\section{Methods}

This systematic review was conducted according to PRISMA guidelines ${ }^{9}$. A completed PRISMA checklist can be found in Supplementary File 1. Throughout this paper we use the RR to include its various estimates, including the odds ratio and the hazard ratio. Where results are referred to as "significant" without further detail, this implies $\mathrm{p}<0.05$.

\section{Study inclusion and exclusion criteria}

We sought studies providing data on RRs for current smokers and/or ex-smokers compared to never smokers for one or more of the diseases lung cancer, COPD, IHD and stroke. Studies providing data from which RRs could be calculated were accepted, as well as those giving the estimates directly.

For lung cancer, attention was restricted to epidemiological prospective or case-control studies involving 100 lung cancers or more, extending our earlier review ${ }^{4}$ of studies published in the 1900s. That review considered specific histological types of lung cancer, but here we restrict attention to overall lung cancer.

For COPD, cross-sectional studies were also considered, and there was no restriction on number of cases, thus extending an earlier review ${ }^{7}$ of studies published before 2007. That review also considered chronic bronchitis and emphysema, but we limit attention to studies using the definitions of COPD described there. We also follow the exclusion criteria given in that review.

For IHD and stroke, we extend an earlier review, described in a supplementary file to a recent publication ${ }^{8}$, which considered studies of prospective or case-control design which involved at least 100 CVD cases and were published between 1990 and 2010. We restricted attention to studies providing data for IHD, acceptable disease definitions including coronary heart disease and acute myocardial infarction, and/or for stroke. Studies providing results only for specific disease subtypes, or only for combined CVD were not included.

While for lung cancer and COPD we accepted studies only providing RRs for the sexes combined, for IHD and stroke the studies had to provide sex-specific RRs. Also for IHD and stroke, studies had to provide RRs adjusted at least for age.

\section{Literature searches}

Studies satisfying the specific criteria were first sought from the three earlier reviews ${ }^{4,7,8}$. Additional papers were also sought from recent reviews of the evidence relating quitting smoking to these diseases $^{10-13}$. Finally Medline searches were conducted to update the evidence considered. The searches were conducted along the lines considered in the three earlier reviews $s^{4,7,8}$ but restricted to Japan and to a later publication date range - from 2000 for lung cancer, from 2007 for COPD, and from 2010 for IHD and stroke, all searches being conducted in early 2017. No attempt was made to consider studies on IHD and stroke published before 1990. In all the searches, abstracts were first examined, with potentially relevant papers then being obtained and examined in detail.

\section{Identification of studies}

The earlier reviews $s^{4,7,8,10-13}$ had already allocated relevant papers to studies, noting multiple papers on the same study, and papers reporting on multiple studies. Similar procedures were carried out to continue this process, with some new publications providing updated information on existing studies. As previously, potential overlaps between studies were noted.

\section{Data recorded}

We extended existing databases to include the additional RRs for current or ex-smoking. All estimates considered were for smoking cigarettes only, cigarettes undefined, or any product. The never smoking denominator could include those who never smoked anything, or never smoked cigarettes. RRs were included, where available, for current smoking overall and for sets of RRs grouped by amount smoked, and for ex-smoking overall and for sets of RRs grouped by time quit. As previously, nearequivalent definitions were accepted when exact definitions were not available (e.g. never smokers could include long-term ex-smokers and recent quitters could be treated as current rather than ex-smokers). Given a choice, the RR adjusted for the most potential confounding variables was selected. Sexes-combined RRs were entered only if sex-specific estimates were unavailable. Age-specific RRs were entered, where available, for IHD and stroke, but not for lung cancer or COPD.

\section{Derivation of RRs}

Where necessary RRs were derived from data provided using standard methods, as described elsewhere ${ }^{4}$. 


\section{Meta-analyses}

Fixed-effect and random-effects meta-analyses were calculated using standard methods ${ }^{14}$ with between estimated heterogeneity quantified by $\mathrm{H}$, the ratio of the heterogeneity chisquared to its degrees of freedom. This is directly related to the I-squared statistic $^{15}$ by the formula $\mathrm{I}^{2}=100(\mathrm{H}-1) / \mathrm{H}$. For all meta-analyses, Egger's test of publication bias ${ }^{16}$ was also included. Analyses were conducted for current smoking overall and for ex-smoking overall, preferring cigarette only smoking versus never smoking of anything where there was a choice of definition, and also for about 5, 20 and 45 cigarettes currently smoked and about 12, 7 and 3 years quit for ex-smokers. For an RR to be included in these two dose-response analyses, the grouped level had to include the stated value, but not either of the other two. For IHD and stroke, 20 was replaced by 19 in the above scheme for amount smoked so as to maximise usage of the available data.

For current smoking overall and for ex-smoking overall, metaanalyses were conducted separately by sex with the significance of the between sex difference also estimated. Where sufficient data were available, we also conducted tests of variation by levels of other factors, which varied by disease.

\section{Study quality and risk of bias}

We did not attempt to derive study-specific scores based on study quality and risk of bias, as the relative importance of different sources of bias or poor quality cannot be reliably assessed. Instead we carried out some meta-analyses showing how estimates varied by aspects of study quality and bias, including study size, number of adjustment variables, and study type. We also considered factors affecting quality and bias in the discussion section.

\section{Results}

Searches

For lung cancer, the earlier review ${ }^{4}$ included 19 studies conducted in Japan, of which 11 provided relevant data. Three additional relevant studies were reported in the quitting review ${ }^{11}$ with a further 12 found from the updated Medline search.

For COPD, the earlier review ${ }^{7}$ included four studies in Japan, one rejected as having no relevant data and the results from another later being found to be superseded by a more recent publication. No additional studies were identified in the quitting review ${ }^{13}$ but the updated Medline search found four further relevant studies.

For IHD and stroke, the earlier review ${ }^{8}$ included four relevant publications, three describing individual studies and one a pooled analysis of three studies. One additional study was identified in the quitting reviews ${ }^{10,12}$, and four additional relevant publications were identified from the Medline search, three describing individual studies and one a pooled analysis of ten studies.

Supplementary File 2 provides fuller details of the literature searches.

\section{Studies identified}

Table 1 gives details of the 40 studies included in the analyses, presented in order of the date of the publication reporting the relevant results. Of these, the numbers giving results for lung cancer, COPD, IHD and stroke are, respectively, 26, seven, nine and seven, some studies reporting on more than one of these diseases. The table provides information for each study on the study type, the location, the years in which it was conducted, the

\section{Table 1. Details of studies included.}

\begin{tabular}{|c|c|c|c|c|c|c|c|c|c|}
\hline \multirow{2}{*}{ Study ref } & \multirow{2}{*}{$\begin{array}{l}\text { Year of } \\
\text { Publ. }\end{array}$} & \multirow{2}{*}{$\begin{array}{l}\text { Study } \\
\text { type }\end{array}$} & \multirow{2}{*}{$\begin{array}{l}\text { Location in } \\
\text { Japan }\end{array}$} & \multirow{2}{*}{ Years $^{b}$} & \multirow{2}{*}{ Population } & \multicolumn{4}{|c|}{ Number of cases ${ }^{d}$} \\
\hline & & & & & & LC & COPD & IHD & Stroke \\
\hline HITOSU 17 & 1968 & $\mathrm{CC}$ & $\begin{array}{l}\text { Amagaski, } \\
\text { Nishinomiya }\end{array}$ & 1960-1966 & Aged 35-74 & 216 & & & \\
\hline SEGI2 ${ }^{18}$ & 1979 & $\mathrm{CC}$ & Tokyo, Sendai & $1962-1970$ & Any age & 378 & & & \\
\hline TSUGAN $^{19}$ & 1987 & $\mathrm{CC}$ & National & $1976-1985$ & Aged 30-49 & 185 & & & \\
\hline SOBUE2 20 & 1988 & $\mathrm{CC}$ & Osaka & $1965-1983$ & Aged 20+ & 2083 & & & \\
\hline HIRAYA ${ }^{21}$ & 1990 & $\mathrm{P}$ & Six prefectures & $1965 / 1982$ & Aged 40+ & 1917 & & 3548 & 12732 \\
\hline YAMAGU $^{22}$ & 1992 & $\mathrm{CC}$ & Kitakyushu & 1989-1990 & Any age & 144 & & & \\
\hline $\mathrm{GAO}^{23}$ & 1993 & $\mathrm{CC}$ & Tokai area & 1984-1986 & Aged 30-84 & 282 & & & \\
\hline SOBUE $^{24}$ & 1994 & $\mathrm{CC}$ & Osaka & $1986-1991$ & Any age & 1376 & & & \\
\hline KIHARA $^{25}$ & 1995 & $\mathrm{CC}$ & Kanagawa & $1991-1993$ & Any age & 447 & & & \\
\hline WAKAl ${ }^{26}$ & 1997 & $\mathrm{CC}$ & Okinawa & 1988-1991 & Aged 40-89 & 333 & & & \\
\hline STELL2 ${ }^{3}$ & 2001 & $\mathrm{CC}$ & Nagoya & 1993-1998 & Aged 20-81 & 410 & & & \\
\hline JPHC(SOBUE) ${ }^{1}$ & 2002 & $\mathrm{P}$ & National & 1990-1994/1999 & Aged 40-69 & 422 & & & \\
\hline HIRAKI ${ }^{27}$ & 2003 & $\mathrm{CC}$ & Aichi & 1991-2000 & Aged 26-81 & 192 & & & \\
\hline KAWAMI ${ }^{28}$ & 2003 & $\mathrm{P}$ & National & 1980-1999 & Aged 30+ & 106 & & & \\
\hline
\end{tabular}




\begin{tabular}{|c|c|c|c|c|c|c|c|c|c|}
\hline \multirow{2}{*}{ Study ref } & \multirow{2}{*}{$\begin{array}{l}\text { Year of } \\
\text { Publ. }\end{array}$} & \multirow{2}{*}{$\begin{array}{l}\text { Study } \\
\text { type }^{\mathrm{a}}\end{array}$} & \multirow{2}{*}{$\begin{array}{l}\text { Location in } \\
\text { Japan }\end{array}$} & \multirow{2}{*}{ Years $^{b}$} & \multirow{2}{*}{ Population ${ }^{c}$} & \multicolumn{4}{|c|}{ Number of cases ${ }^{d}$} \\
\hline & & & & & & LC & COPD & IHD & Stroke \\
\hline MINAMI $^{29}$ & 2003 & $\mathrm{CC}$ & Miyagi & $1997-2001$ & Aged 40 & 515 & & & \\
\hline YAMAGI ${ }^{30}$ & 2003 & $P$ & $\begin{array}{l}\text { Ikawa, Kyowa, } \\
\text { Yao City }\end{array}$ & $1975 / 1986$ & Men aged 40-69 & & & 100 & 257 \\
\hline $\mathrm{FUKUCH}^{31}$ & 2004 & CS & 18 prefectures & 2000 & Aged 40+ & & 256 & & \\
\hline MARUG2 $2^{32}$ & 2004 & $\mathrm{CC}$ & $\begin{array}{l}\text { Osaka, Okinawa, } \\
\text { Nagano }\end{array}$ & 1996-1998 & Aged 40-79 & 1115 & & & \\
\hline UESHIM ${ }^{33}$ & 2004 & $\mathrm{P}$ & National & $1980 / 1994$ & Aged 30+ & & & 69 & 203 \\
\hline $\mathrm{KANASH}^{34}$ & 2005 & $\mathrm{CC}$ & Ibaraki & 1997-2003 & Men aged 50-79 & 363 & & & \\
\hline MARUG $1^{35}$ & 2005 & $\mathrm{P}$ & Three prefectures & 1983-1990/2000 & Aged 40-80 & 598 & & & \\
\hline TSUSHI ${ }^{36}$ & 2006 & CS & $\begin{array}{l}\text { Azumi, Kouhoku, } \\
\text { Nagano }\end{array}$ & 2003-2004 & Mean age 54 & & 48 & & \\
\hline JACC $(\mathrm{OZASA})^{37}$ & 2007 & $\mathrm{P}$ & 45 areas & 1988-1990/2003 & Aged 40-79 & 1087 & & & \\
\hline KOJIM2238 & 2007 & CS & Tokyo & 1997-2005 & Aged 25-74 & & 466 & & \\
\hline OSAKI ${ }^{39}$ & 2007 & $\mathrm{P}$ & Tottori & 1995/1999 & Men of any age & 119 & & & \\
\hline HIRAY2 ${ }^{40}$ & 2009 & $\mathrm{CC}$ & Aichi, Gifu, Kyoto & 2006 & Aged 56-75 & & 278 & & \\
\hline 3 STUDIES ${ }^{41,42}$ & 2010 & $P$ & Nationale $^{\mathrm{e}}$ & 1983-1993/2003 & Aged 40-79 & 968 & & 493 & 1472 \\
\hline $\mathrm{KIYOHA}^{43}$ & 2010 & $\mathrm{CC}$ & Kyushu & 1996-2008 & Any age & 462 & & & \\
\hline OSAKA ${ }^{44}$ & 2010 & CS & Takahata & 2004-2005 & Aged 40+ & & 308 & & \\
\hline JPHC(SHIMAZU) ${ }^{45}$ & 2010 & $P$ & National & 1995-1999/2005 & Aged 45-74 & 481 & & & \\
\hline $\mathrm{KONDO}^{46}$ & 2011 & $\mathrm{P}$ & $\begin{array}{l}\text { Seven } \\
\text { workplaces }\end{array}$ & 2000-2008/2008 & $\begin{array}{l}\text { Male workers } \\
\text { aged } 20-61\end{array}$ & & & 37 & 73 \\
\hline OMORI2 ${ }^{47}$ & 2011 & CS & Kumamoto & 1994-1999 & $\begin{array}{l}\text { Males aged } \\
30-76\end{array}$ & & 91 & & \\
\hline $\mathrm{AKIBA}^{48}$ & 2012 & $P$ & $\begin{array}{l}\text { Hiroshima, } \\
\text { Nagasaki }\end{array}$ & 1958/1999 & $\begin{array}{l}\text { Atomic bomb } \\
\text { survivors - any } \\
\text { age }\end{array}$ & 610 & & & \\
\hline 10 STUDIES $^{49}$ & 2012 & $P$ & National $^{\dagger}$ & $\begin{array}{l}\text { 1977-1997/ } \\
\text { Varies }\end{array}$ & Aged 40-89 & & & 382 & 893 \\
\hline HORIE $^{50}$ & 2013 & CS & Tokyo & 2001-2008 & Aged 30+ & & 1035 & & \\
\hline $\mathrm{ITO}^{51}$ & 2013 & $\mathrm{CC}$ & Aichi & 2001-2005 & Any age & 1552 & & & \\
\hline JPHC(ESHAK $)^{52}$ & 2014 & $P$ & National & 1990-1993/2009 & Aged 45-74 & & & 584 & \\
\hline $\mathrm{FUKUMO}^{53}$ & 2015 & $\mathrm{CC}$ & Aichi & 1993-1998 & Aged 20-81 & 625 & & & \\
\hline HATANA $^{54}$ & 2015 & $P$ & National & 2003/2011 & $\begin{array}{l}\text { Men aged } \\
30-55 \text { in health } \\
\text { insurance } \\
\text { program }\end{array}$ & & & 238 & \\
\hline JACC(MATSUNAGA) $)^{55}$ & 2017 & $P$ & 45 areas & 1988-1990/2009 & Aged 40-79 & & & 1554 & 3163 \\
\hline \multicolumn{10}{|c|}{$\begin{array}{l}\mathrm{b} *=\text { unknown. Values in brackets are approximate, based on one year before the first publication. For prospective studies, baseline year(s)/final follow-up } \\
\text { year. }\end{array}$} \\
\hline \multicolumn{10}{|c|}{ ' Unless shown otherwise in this column, the study specified no major inclusion or exclusion criteria. } \\
\hline \multicolumn{10}{|c|}{ din whole study. } \\
\hline \multicolumn{10}{|c|}{$\begin{array}{l}\text { e Combined results from three prospective studies; the JPHC and JACC studies had wide national coverage, and the TPCS was conducted in three } \\
\text { prefectures (Miyagi, Aichi, Osaka). The first reference cited gives the lung cancer findings and the second the cardiovascular findings. }\end{array}$} \\
\hline Combined results from ten & prospective & studies, & ach with at least 10 ye & ars follow-up. These ir & cluded the JACC stu & & & & \\
\hline
\end{tabular}


population considered, and the number of cases of each disease it considered. Two publications based on the Japan Collaborative Cohort (JACC) are treated as separate studies in the table as the publications relate to different diseases and periods of follow-up. The same is true for three publications based on the Japan Public Health Center (JPHC) study.

Two pooled analyses of results are treated as single studies in Table 1. The pooled analysis of three studies reported by Wakai et $a l^{41}$ for lung cancer and by Honjo et $a l^{42}$ for CVD included results from the JACC, JPHC and MARUG1 studies. It may have some overlap of results for lung cancer with the findings from JACC (OZASA), JPHC (SOBUE and SHIMAZU) and MARUG1 and for CVD with the findings from JACC (MATSUNAGA) and JPHC (ESHAK). The pooled analysis of ten studies on CVD by Nakamura et $a l^{49}$ may have some overlap of results with the findings from UESHIM and JACC (MATSUNAGA), but is predominantly based on studies not considered elsewhere.

Of the 40 studies, 18 are case-control and 6 of cross-sectional design (all of COPD), with the rest prospective. Ten of the studies were published before 2000, although 20 had been completed by then. The largest study was HIRAYA, which involved 1917 lung cancer cases, 3,548 cases of IHD and 12,732 of stroke, though the SOBUE2 study involved somewhat more lung cancer cases, 2,083.

\section{Relative risks included}

Table 2 gives the RRs for current and ex-smoking while Supplementary File 3 gives them by amount smoked and time quit. As seen in Table 2, most lung cancer estimates are adjusted for age plus at most one other potential confounding variable, while nearly all COPD estimates are unadjusted, even for age. All the IHD and stroke estimates are (as required) adjusted for age, and most of these also for a number of additional variables.

Meta-analyses

Meta-analysis results (random effects estimates) are shown for current smoking in Table 3, for amount smoked by current smokers in Table 4, for ex-smoking in Table 5 and for time quit by ex-smokers in Table 6. Supplementary File 4 gives some additional results for current and ex-smoking for lung cancer, IHD and stroke. Below we summarize the results by disease risk.

Table 2. Relative risks for current and for ex-smokers (vs never smokers).

\begin{tabular}{|c|c|c|c|c|c|c|}
\hline \multirow[t]{2}{*}{ Disease } & \multirow[t]{2}{*}{ Study ref } & \multirow[t]{2}{*}{ Sex } & \multirow[t]{2}{*}{ Age } & \multicolumn{2}{|c|}{ Relative risks $(95 \% \mathrm{Cl})$} & \multirow[t]{2}{*}{ Adjustment factors } \\
\hline & & & & Current smoker & Ex-smoker & \\
\hline \multirow[t]{23}{*}{ Lung cancer } & HITOSU & M & & $2.79(1.27-6.09)$ & $3.95(1.63-9.55)$ & Age \\
\hline & & $\mathrm{F}$ & & 3.09 (1.82-5.27) & $6.72(2.55-17.68)$ & Age \\
\hline & SEGI2 & M & & $3.74(1.75-8.00)$ & - & Age \\
\hline & & $\mathrm{F}$ & & 1.65 (0.90-3.02) & - & Age \\
\hline & TSUGAN & M & & $1.22(0.60-2.50)$ & $1.53(0.50-4.68)$ & None \\
\hline & SOBUE2 & M & & $4.47(3.89-5.14)$ & - & Age +1 \\
\hline & & $\mathrm{F}$ & & $3.28(2.79-3.87)$ & - & Age +1 \\
\hline & HIRAYA & M & & $4.45(3.60-5.50)$ & $1.71(1.08-2.72)$ & Age \\
\hline & & $\mathrm{F}$ & & $2.34(1.87-2.92)$ & $2.98(1.14-7.77)$ & Age \\
\hline & YAMAGU & $M+F$ & & $4.90(2.55-9.44)$ & $2.90(1.43-5.90)$ & Age \\
\hline & GAO2 & M & & $6.61(3.47-12.58)$ & $3.56(1.83-6.91)$ & Age \\
\hline & SOBUE & M & & $4.10(2.80-5.90)$ & $2.80(1.90-4.20)$ & Age \\
\hline & & $\mathrm{F}$ & & $2.80(2.00-3.90)$ & $2.10(1.40-3.20)$ & Age \\
\hline & KIHARA & $M+F$ & & $4.06(3.00-5.49)$ & $1.83(1.20-2.79)$ & None \\
\hline & WAKAI & M & & $4.40(2.19-8.85)$ & $2.43(1.16-5.06)$ & Age +1 \\
\hline & & $\mathrm{F}$ & & $4.37(2.21-8.62)$ & $5.33(1.21-23.50)$ & Age +1 \\
\hline & STELL2 & M & & 6.30 (3.70-10.90) & $2.20(1.30-4.00)$ & Age +1 \\
\hline & JPHC(SOBUE) & M & & $4.50(3.00-6.80)$ & $2.20(1.40-3.40)$ & Age +1 \\
\hline & & $\mathrm{F}$ & & $4.20(2.40-7.20)$ & $3.70(1.40-10.20)$ & Age +1 \\
\hline & HIRAK1 & $M+F$ & & $2.11(1.35-3.31)$ & $1.65(0.99-2.75)$ & 1 (not age) \\
\hline & KAWAMI & M & & $6.76(2.13-21.48)$ & $2.35(0.62-8.91)$ & Age \\
\hline & & $\mathrm{F}$ & & $3.67(1.55-8.68)$ & - & Age \\
\hline & MINAMI & M & & $4.75(3.04-7.42)$ & $2.74(1.71-4.38)$ & Age +4 \\
\hline
\end{tabular}




\begin{tabular}{|c|c|c|c|c|c|c|}
\hline \multirow[t]{2}{*}{ Disease } & \multirow[t]{2}{*}{ Study ref } & \multirow[t]{2}{*}{ Sex } & \multirow[t]{2}{*}{ Age } & \multicolumn{2}{|c|}{ Relative risks $(95 \% \mathrm{Cl})$} & \multirow[t]{2}{*}{ Adjustment factors } \\
\hline & & & & Current smoker & Ex-smoker & \\
\hline & & $\mathrm{F}$ & & $1.91(1.14-3.18)$ & $2.37(1.08-5.23)$ & Age +4 \\
\hline & MARUG2 & M & & $2.78(1.94-4.00)$ & $2.46(1.47-4.12)$ & Age +1 \\
\hline & & $\mathrm{F}$ & & $2.34(1.46-3.74)$ & $0.93(0.47-1.81)$ & Age +1 \\
\hline & KANASH & M & & $6.31(3.33-11.97)$ & $2.97(1.55-5.70)$ & Age +1 \\
\hline & MARUG1 & M & & $5.10(3.34-7.79)$ & $2.60(1.65-4.10)$ & Age +1 \\
\hline & & $\mathrm{F}$ & & $3.66(2.50-5.35)$ & $2.94(1.63-5.31)$ & Age +1 \\
\hline & JACC(OZASA) & M & & $4.94(3.77-6.47)$ & $2.20(1.63-2.96)$ & Age +1 \\
\hline & & $\mathrm{F}$ & & $4.25(2.98-6.05)$ & $2.19(1.07-4.48)$ & Age +1 \\
\hline & OSAKI & M & & $4.90(2.80-8.40)$ & $2.20(1.20-4.10)$ & Age \\
\hline & 3 STUDIES & M & & $4.71(3.76-5.89)$ & $2.10(1.66-2.67)$ & Age +1 \\
\hline & KIYOHA & $M+F$ & & $2.10(1.55-2.84)$ & $3.70(2.44-5.60)$ & None \\
\hline & JPHC(SHIMAZU) & M & & $3.29(2.55-4.24)$ & $2.53(1.85-3.45)$ & 1 (not age) \\
\hline & $\mathrm{AKIBA}^{\mathrm{a}}$ & M & Any & $3.19(2.27-4.47)$ & $2.50(1.50-4.30)$ & 1 (not age), age +4 \\
\hline & & $\mathrm{F}$ & Any & $3.14(2.55-3.88)$ & $1.40(0.70-2.60)$ & 1 (not age), age +4 \\
\hline & ITO & $M+F$ & & $4.34(3.47-5.44)$ & $2.02(1.60-2.55)$ & Age +4 \\
\hline & FUKUMO & $M+F$ & & $3.40(2.71-4.27)$ & $1.34(1.02-1.75)$ & None \\
\hline \multirow[t]{10}{*}{ COPD } & FUKUCH & $M+F$ & & $2.96(2.14-4.09)$ & $2.99(2.12-4.22)$ & None \\
\hline & TSUSHI & $M+F$ & & $5.79(2.51-13.38)$ & $4.81(1.93-12.00)$ & None \\
\hline & KOJIM2 & M & & $2.55(1.88-3.46)$ & $1.68(1.20-2.34)$ & None \\
\hline & & $\mathrm{F}$ & & $1.11(0.45-2.77)$ & $0.18(0.01-2.92)$ & None \\
\hline & HIRAY2 & M & & $21.31(6.35-71.48)$ & $35.81(11.06-115.94)$ & None \\
\hline & & $\mathrm{F}$ & & $56.70(9.54-337.02)$ & $84.00(18.42-382.98)$ & None \\
\hline & OSAKA & $M+F$ & & $2.74(2.16-3.48)$ & $2.48(1.89-3.25)$ & None \\
\hline & OMORI2 & M & & $4.73(2.36-9.46)$ & $2.39(1.24-4.59)$ & Age +1 \\
\hline & HORIE & M & & $3.59(2.98-4.33)$ & $2.00(1.66-2.40)$ & Age \\
\hline & & $\mathrm{F}$ & & $3.68(2.27-5.96)$ & $0.77(0.31-1.91)$ & Age \\
\hline \multirow[t]{17}{*}{ IHD } & HIRAYA & M & $40+$ & $1.73(1.52-1.97)$ & $1.39(1.06-1.83)$ & Age \\
\hline & & $\mathrm{F}$ & $40+$ & $1.90(1.66-2.18)$ & $0.73(0.24-2.24)$ & Age \\
\hline & YAMAGI & M & $40-69$ & $4.39(1.57-12.24)$ & $3.70(1.20-11.20)$ & Age +11 \\
\hline & UESHIM & M & $30+$ & $2.14(0.77-5.91)$ & $1.00(0.28-3.53)$ & Age +5 \\
\hline & & $\mathrm{F}$ & $30+$ & $1.24(0.33-4.65)$ & $0.87(0.11-6.70)$ & Age \\
\hline & 3 STUDIES & M & $40-64$ & $2.50(1.88-3.34)$ & $1.78(1.28-2.46)$ & Age +1 \\
\hline & & M & $65-79$ & $1.92(1.46-2.53)$ & $1.68(1.26-2.24)$ & Age +1 \\
\hline & & $\mathrm{F}$ & $40-64$ & $4.36(3.01-6.32)$ & $2.79(1.30-6.00)$ & Age +1 \\
\hline & & $\mathrm{F}$ & $65-79$ & $2.21(1.62-3.02)$ & $2.22(1.44-3.40)$ & Age +1 \\
\hline & KONDO & M & $20-61$ & $4.76(1.40-16.25)$ & $0.83(0.15-4.50)$ & Age +3 \\
\hline & 10 STUDIES & M & $40-64$ & $2.25(1.21-4.21)$ & $0.83(0.34-1.98)$ & Age +4 \\
\hline & & M & $65-89$ & $2.01(1.26-3.22)$ & $1.11(0.63-1.96)$ & Age +4 \\
\hline & & $\mathrm{F}$ & $40-64$ & $3.52(1.61-7.68)$ & $4.25(1.01-17.94)$ & Age +4 \\
\hline & & $\mathrm{F}$ & $65-89$ & $2.89(1.73-4.83)$ & $1.90(0.77-4.71)$ & Age +4 \\
\hline & JPHC & M & $45-74$ & $2.26(1.79-2.87)$ & $1.09(0.83-1.43)$ & Age +14 \\
\hline & & $\mathrm{F}$ & $45-74$ & $2.89(1.94-4.30)$ & $\begin{array}{l}\text { No cases in } \\
\text { ex-smokers }\end{array}$ & Age +14 \\
\hline & HATANA & M & 30-39 & $2.17(1.08-4.34)$ & - & Age +8 \\
\hline
\end{tabular}




\begin{tabular}{|c|c|c|c|c|c|c|}
\hline \multirow[t]{2}{*}{ Disease } & \multirow[t]{2}{*}{ Study ref } & \multirow[t]{2}{*}{ Sex } & \multirow[t]{2}{*}{ Age } & \multicolumn{2}{|c|}{ Relative risks $(95 \% \mathrm{Cl})$} & \multirow[t]{2}{*}{ Adjustment factors } \\
\hline & & & & Current smoker & Ex-smoker & \\
\hline & & M & $40-55$ & $1.34(1.01-1.79)$ & - & Age +8 \\
\hline & JACC & M & $40-79$ & 1.95 (1.58-2.39) & $1.29(1.02-1.63)$ & Age +6 \\
\hline & & $\mathrm{F}$ & $40-79$ & $2.45(1.89-3.18)$ & $1.07(0.58-1.95)$ & Age +8 \\
\hline \multirow[t]{16}{*}{ Stroke } & HIRAYA & M & $40+$ & $1.08(1.02-1.14)$ & $0.99(0.87-1.13)$ & Age \\
\hline & & $\mathrm{F}$ & $40+$ & $1.18(1.10-1.28)$ & $1.53(1.08-2.15)$ & Age \\
\hline & YAMAGI & M & $40-69$ & $1.41(0.97-2.06)$ & $0.80(0.50-1.30)$ & Age +11 \\
\hline & UESHIM & M & $30+$ & $1.69(0.98-2.93)$ & $1.56(0.84-2.90)$ & Age +5 \\
\hline & & $\mathrm{F}$ & $30+$ & $1.66(0.91-3.03)$ & $1.31(0.50-3.39)$ & Age +5 \\
\hline & 3 STUDIES & M & $40-64$ & $1.41(1.16-1.71)$ & $0.97(0.77-1.22)$ & Age +1 \\
\hline & & M & $65-79$ & $1.13(0.95-1.33)$ & $1.02(0.85-1.21)$ & Age +1 \\
\hline & & F & $40-64$ & $2.75(2.15-3.53)$ & $1.85(1.10-3.10)$ & Age +1 \\
\hline & & $\mathrm{F}$ & $65-79$ & $1.24(0.99-1.56)$ & $1.09(0.77-1.53)$ & Age +1 \\
\hline & KONDO & M & $20-61$ & $2.17(1.09-4.30)$ & $1.00(0.42-2.41)$ & Age +3 \\
\hline & 10 STUDIES & M & $40-64$ & $2.58(1.54-4.33)$ & $1.40(0.72-2.71)$ & Age +4 \\
\hline & & M & $65-89$ & $1.36(1.02-1.81)$ & $1.02(0.73-1.43)$ & Age +4 \\
\hline & & $\mathrm{F}$ & $40-64$ & $1.79(0.98-3.26)$ & $2.11(0.67-6.68)$ & Age +4 \\
\hline & & F & $65-89$ & $1.17(0.75-1.83)$ & $1.25(0.64-2.43)$ & Age +4 \\
\hline & JACC & M & $40-79$ & $1.23(1.07-1.42)$ & $0.91(0.78-1.06)$ & Age +6 \\
\hline & & $\mathrm{F}$ & $40-79$ & $1.35(1.08-1.68)$ & $0.97(0.66-1.43)$ & Age +8 \\
\hline
\end{tabular}

${ }^{a}$ Ex-smoker data are from an earlier reference ${ }^{56}$

Table 3. Meta-analyses for current smoking.

\begin{tabular}{|c|c|c|c|c|c|c|}
\hline Characteristic & Level & Statistic $^{a}$ & Lung cancer & COPD & IHD & Stroke \\
\hline \multirow[t]{3}{*}{ All } & All & $\mathrm{n}$ & 39 & 10 & 20 & 16 \\
\hline & & $\mathrm{R}$ & $3.59(3.25-3.96)$ & $3.57(2.72-4.70)$ & $2.21(1.96-2.50)$ & $1.40(1.25-1.57)$ \\
\hline & & $\mathrm{H}, \mathrm{P}_{\mathrm{H}}$ & $2.98, p<0.001$ & $3.71, p<0.001$ & $2.53, p<0.001$ & $5.21, p<0.001$ \\
\hline \multirow[t]{7}{*}{ Sex } & Male & $\mathrm{n}$ & 20 & 4 & 12 & 9 \\
\hline & & $\mathrm{R}$ & $4.20(3.74-4.72)$ & $4.07(2.59-6.40)$ & $1.98(1.74-2.25)$ & $1.32(1.16-1.51)$ \\
\hline & Female & $n$ & 13 & 3 & 8 & 7 \\
\hline & & $\mathrm{R}$ & $3.00(2.61-3.44)$ & $4.90(1.08-22.26)$ & $2.59(2.06-3.27)$ & $1.50(1.16-1.94)$ \\
\hline & Combined & $\mathrm{n}$ & 6 & 3 & 0 & 0 \\
\hline & & $\mathrm{R}$ & $3.27(2.51-4.28)$ & $3.00(2.34-3.85)$ & - & - \\
\hline & Between levels & $P_{B}$ & $<0.001$ & NS & $<0.05$ & $<0.01$ \\
\hline
\end{tabular}

${ }^{a} n=$ number of estimates combined, $R=$ random-effects meta-analysis $R R(95 \% \mathrm{Cl}), \mathrm{H}=$ heterogeneity chisquared per degree of freedom, $P_{H}=$ probability value for heterogeneity expressed as $p<0.001, p<0.01, p<0.05, p<0.1$ or $N S(p \geq 0.1) . P_{B}=$ probability value for between level comparison similarly expressed. 
Table 4. Meta-analysis for amount smoked by current smokers.

\begin{tabular}{|c|c|c|c|c|c|}
\hline Amount smoked & Statistic $^{a}$ & Lung Cancer & COPD & IHD & Stroke \\
\hline Number of sets ${ }^{b}$ & & 21 & 0 & 12 & 8 \\
\hline \multirow[t]{2}{*}{ About 5 cigs/day } & $n$ & 16 & - & 5 & 5 \\
\hline & $\mathrm{R}$ & $2.89(2.44-3.43)$ & & $1.71(1.50-1.94)$ & $1.38(1.15-1.65)$ \\
\hline \multirow[t]{2}{*}{ About 20 cigs/day ${ }^{c}$} & $n$ & 12 & - & 5 & 5 \\
\hline & $\mathrm{R}$ & $4.43(3.68-5.34)$ & & $1.91(1.55-2.35)$ & $1.29(1.07-1.56)$ \\
\hline \multirow[t]{2}{*}{ About 45 cigs/day } & $n$ & 16 & - & 11 & 8 \\
\hline & $\mathrm{R}$ & $6.42(5.14-8.02)$ & & $2.70(2.16-3.39)$ & $1.64(1.21-2.22)$ \\
\hline
\end{tabular}

${ }^{a} n=$ Number of estimates combined, $\mathrm{R}=$ random effects meta-analysis $\mathrm{RR}(95 \% \mathrm{Cl})$.

${ }^{b}$ Number of sets of RRs available for the key value analyses, where the dose for comparison is never smoked. See also Supplementary File 3 for details.

'Base for comparison is never smoked. For lung cancer and COPD; the first category for which results are provided includes 5 cigs/day, but does not include 20 cigs/day; the second includes 20 cigs/day, but does not include 5 or 45 cigs/day; and the third includes 45 cigs/day, but does not include 20 cigs/day. For IHD and stroke; 20 cigs/day is replaced by 19.

\begin{tabular}{|c|c|c|c|c|c|c|}
\hline Characteristic & Level & Statistic $^{a}$ & Lung cancer & COPD & IHD & Stroke \\
\hline \multirow[t]{3}{*}{ All } & All & $n$ & 34 & 10 & 17 & 16 \\
\hline & & $\mathrm{R}$ & $2.26(2.03-2.52)$ & $3.03(2.00-4.57)$ & $1.46(1.24-1.71)$ & $1.05(0.96-1.15)$ \\
\hline & & $\mathrm{H}, \mathrm{P}_{\mathrm{H}}$ & $1.50,<0.05$ & $6.89,<0.001$ & $1.58,<0.1$ & 1.26, NS \\
\hline \multirow[t]{7}{*}{ Sex } & Male & $n$ & 18 & 4 & 10 & 9 \\
\hline & & $\mathrm{R}$ & $2.36(2.12-2.63)$ & $3.04(1.65-5.62)$ & $1.37(1.18-1.61)$ & $0.98(0.91-1.06)$ \\
\hline & Female & $n$ & 10 & 3 & 7 & 7 \\
\hline & & $\mathrm{R}$ & $2.35(1.70-3.25)$ & $2.50(0.07-85.77)$ & $1.75(1.17-2.60)$ & $1.29(1.06-1.55)$ \\
\hline & Combined & $n$ & 6 & 2 & 0 & 0 \\
\hline & & $\mathrm{R}$ & $2.04(1.51-2.75)$ & $2.77(2.21-3.48)$ & - & - \\
\hline & Between levels & $P_{B}$ & NS & $<0.1$ & $<0.01$ & $<0.01$ \\
\hline
\end{tabular}




\begin{tabular}{|c|c|c|c|c|c|}
\hline Duration of quitting & Statistic $^{a}$ & Lung Cancer & COPD & IHD & Stroke \\
\hline Number of sets ${ }^{b}$ & & 11 & $1^{\mathrm{c}}$ & 4 & 4 \\
\hline \multirow[t]{2}{*}{ About 12 years ${ }^{d}$} & $n$ & 9 & - & 4 & 4 \\
\hline & $\mathrm{R}$ & $2.08(1.65-2.61)$ & & $1.22(0.81-1.84)$ & $0.95(0.72-1.23)$ \\
\hline \multirow[t]{2}{*}{ About 7 years ${ }^{d}$} & $n$ & 8 & - & 4 & 4 \\
\hline & $\mathrm{R}$ & $2.87(2.32-3.56)$ & & $2.08(1.48-2.90)$ & $1.13(0.85-1.50)$ \\
\hline \multirow[t]{2}{*}{ About 3 years ${ }^{d}$} & $n$ & 9 & - & 4 & 4 \\
\hline & $\mathrm{R}$ & $3.70(3.12-4.40)$ & & $2.10(1.20-3.69)$ & $1.28(1.11-1.48)$ \\
\hline \multicolumn{6}{|c|}{${ }^{a} \mathrm{n}=$ Number of estimates combined, $\mathrm{R}=$ random effects meta-analysis $\mathrm{RR}(95 \% \mathrm{CI})$} \\
\hline \multicolumn{6}{|c|}{$\begin{array}{l}{ }^{b} \text { Number of sets of RRs available for the key value analyses, where the comparison is with never smoked. See } \\
\text { also Supplementary File } 3 \text { for details. }\end{array}$} \\
\hline \multicolumn{6}{|c|}{$\begin{array}{l}\text { " One study reported RRs ( } 95 \% \text { Cls) of } 2.08(1.08-4.00) \text { for "early quitters" and } 2.42(1.11-5.25) \text { for "late } \\
\text { quitters", early quitters having reported current smoking in } 1994 \text { but not in } 1999 \text { or } 2006 \text {, and late quitters } \\
\text { having reported current smoking in } 1994 \text { and } 1999 \text { but not in } 2006 .\end{array}$} \\
\hline \multicolumn{6}{|c|}{$\begin{array}{l}\text { d Base for comparison is never smoked. The first category for which results are provided includes quit } 12 \text { years } \\
\text { ago but does not include quit } 7 \text { years ago; the second includes quit } 7 \text { years ago but does not include quit } 3 \text { or } \\
12 \text { years ago; and the third includes quit } 3 \text { years ago but does not include quit } 7 \text { years ago. }\end{array}$} \\
\hline
\end{tabular}

\section{Lung cancer}

For current smoking, the overall RR shown in Table 3 is 3.59 (95\%CI 3.25-3.96), based on 39 estimates. As shown in Table 2, the RRs range from 1.22 to 6.76 , with all but two statistically significant. While the estimates are heterogeneous, no single factor is responsible for this, though (see also Supplementary File 4) there is evidence that RRs are higher in males and where adjusted for more variables. Table 4 shows that the RRs increase steadily with amount smoked, rising from 2.89 (2.44-3.43) for "about 5 cigs/day" to 6.42 (5.14-8.02) for "about 45 cigs/day".

Compared to current smoking the RR for ex-smoking (Table 5) of $2.26(2.03-2.52)$ is lower and shows less heterogeneity, with the only factor showing significant variation being publication year, with RRs higher in older (pre-1980) studies. RRs clearly reduced with increasing time of quit, evident both in the individual data sets for each study and the summary analysis in Table 6.

\section{COPD}

For current smoking, the overall RR shown in Table 3 is 3.57 (95\% CI 2.72-4.70), based on 10 estimates. However, as Table 2 shows, the two RRs from HIRAY2 are atypically high, and excluding these results substantially reduced the heterogeneity and reduced the RR to 3.10 (2.57-3.75). There is no significant variation by sex. Analyses by further subgroups were not attempted, due to the limited number of estimates for which results are available. There are no available results by amount smoked.

For ex-smoking (see Table 5) the overall RR was 3.03 (2.00-4.57). This reduced to $2.16(1.68-2.77)$ after excluding the high results from HIRAY2 (Table 2). A single study reported similar RRs for late quitters and early quitters, as shown in the footnote to Table 6.

\section{IHD}

For current smoking, the overall RR (Table 3) is 2.21 (95\% CI 1.96-2.50). However, the estimates are clearly heterogeneous, with RRs somewhat higher in females than males. The additional results in Supplementary File 4 show that RRs tend to be greater in more recently published studies, but did not vary significantly by age or by the number of variables adjusted for. There was variation by study size, but this did not show any systematic trend. As shown in Table 4, the RRs increase steadily with amount smoked, rising from 1.71 (1.50-1.94) for "about 5 cigs/day" to 2.70 (2.16-3.39) for "about 45 cigs/day".

For ex-smoking, the overall RR (Table 5) of 1.46 (1.24-1.71) is clearly lower than that for current smoking. RRs tended to be higher in females, and in less adjusted estimates. In those who had quit for "about 12 years" the RR at $1.22(0.81-1.84)$ is not significantly increased, but those for shorter quit times are both elevated to a similar extent (Table 6).

\section{Stroke}

For current smoking, the overall RR (Table 3) is 1.40 (95\% CI 1.25-1.57), less elevated for the other diseases. There is clear heterogeneity, RRs tending to be higher in females, for those aged $<65$, in more recently published studies, and in studies involving fewer cases (see also Supplementary File 4).

There is no clear relationship of risk of stroke to amount smoked (Table 4) though the largest estimate is for the highest dose.

Overall, risk is not significantly elevated in former smokers (Table 5) with the RR estimated as 1.05 (0.96-1.15). However, 
the analyses show some increase in females, and in short-term quitters (Table 6).

\section{Publication bias}

Each meta-analysis included a test of publication bias (detailed results not shown).

For lung cancer, there is no evidence of publication bias for current smoking and only marginal evidence $(\mathrm{p}<0.05)$ for ex-smoking, where RRs were somewhat greater in smaller studies. For CVD, the strongest evidence of publication bias $(p=0.003)$ is for the analysis of current smoking RRs for stroke. This corresponds with the evidence of higher risks in smaller studies. No evidence of publication bias is seen for COPD for either current or ex smoking.

\section{Avoiding overlap}

The meta-analyses reported include all available data, accepting some overlap of results between studies. Some additional analyses were conducted for current smoking either omitting results from the publications reporting combined analyses (3 STUDIES, 10 STUDIES) or omitting results from studies considered in these analyses (JPHC, JACC, MARUG1). For lung cancer, compared to the original estimate of 3.59 (95\%CI 3.25-3.96), the first omission gave 3.55 (3.20-3.93) while the second gave 3.46 (3.06-3.91). For IHD, the original RR of 2.21 (1.96-2.50) became $2.01(1.76-2.29)$ for the first omission and $2.20(1.88-$ $2.57)$ for the second. For stroke $1.40(1.25-1.57)$ became 1.22 (1.11-1.34) and 1.44 (1.25-1.65). For CVD it should be noted that omitting the 10 STUDIES results lost relevant information as many of its individual studies were not included elsewhere.

\section{Discussion}

The results presented show some increased risk of all four diseases with current smoking, and a lesser increase with ex-smoking, that with stroke not being clearly significant. The evidence for COPD is clearly the thinnest being based largely on cross-sectional studies and on unadjusted RRs, and providing little or no data for amount smoked or time quit. The other diseases do show a tendency for RRs to increase with amount smoked and to decline with increasing time quit, though again the associations are less clear for stroke, the disease most weakly associated with smoking.

In considering these results, various aspects of the data require comment.

\section{Product used}

Smoking of tobacco products other than cigarettes, such as cigars or pipes, is rare in $\mathrm{Japan}^{57}$ and whether authors related results to unspecified smoking, to cigarette smoking or to cigarette only smoking would be of little practical relevance. Similarly the precise definition of the comparison group, never smokers, is unlikely to be important.

\section{Study type}

For lung cancer, there is no evidence that RRs differ between prospective and case-control studies. Since all the RRs for CVD came from prospective studies, and virtually all those for COPD came from cross-sectional studies, variation by study type could not usefully be examined for these diseases.

\section{Subtypes of disease}

It was beyond the scope of the study to investigate variation by disease subtypes, though we note that, for lung cancer, some studies (e.g. AKIBA, ITO, MARUG2, JPHC(SOBUE)) present evidence consistent with there being higher RRs for squamous cell carcinoma than for adenocarcinoma.

\section{Age-specific results}

It has previously been established that the variation in RR by age is much greater for cardiovascular disease than for lung cancer or $\mathrm{COPD}^{4,7,8}$. For this reason we only considered agespecific data for IHD and stroke. The results generally confirmed the higher RRs in younger individuals.

\section{Adjustment for potential confounding variables}

In order to limit the scope of the project, attention was restricted to RRs adjusted for the most potential confounding variables where there was a choice. For lung cancer, there was some evidence that more adjusted RRs were higher, but for cardiovascular disease no such trend was seen. RRs for COPD were generally unadjusted.

\section{Outliers}

Formal tests for outliers were not attempted, but it was evident from inspection of Table 2 that the very large RRs for the HIRAY2 study were inconsistent with the rest of the available results, and removal of the results from the meta-analysis materially reduced the RRs for both current and ex-smoking. Otherwise there seemed to be no clear outliers, unusually low or high RRs typically having a very wide $95 \% \mathrm{CI}$, being based on limited data.

\section{Other issues}

Imprecision of the effect estimates could have resulted from errors in diagnosis of disease or errors in determining smoking habits. It was notable that mortality studies generally did not rely on autopsy-confirmed diagnosis, and that smoking habits recorded were usually based on self-report by the individual with no confirmation of non-smoking status by measurement of biomarkers such as cotinine.

\section{Comparison with results for Western populations}

Table 7 presents meta-analysis relative risks for current smoking by region from this study, from reviews of ours ${ }^{4,7,8}$ and from other selected recent reviews ${ }^{2,658-60}$ chosen as they provided RR estimates for the sexes combined by region. It was clear for IHD that there is little evidence of a material difference in RR between estimates from Japanese studies and those from studies in other Asian countries or Western countries. In all cases the RR is quite close to 2. The pattern is broadly similar for stroke, with the RR for stroke, typically about 1.4 , less than that for IHD, with the minor exception of Scandinavia, where the RR is based on only two estimates. For COPD, the available data are limited, but provide some suggestion that, compared to Japan, RRs are somewhat higher for North America though similar for Europe. 
Table 7. Current smoking relative risks in the present study compared with those reported in other studies in Japan and elsewhere.

\begin{tabular}{|c|c|c|c|c|}
\hline Disease & Source & Region & $\mathbf{N}$ & $\mathrm{RR}(95 \% \mathrm{Cl})$ \\
\hline \multirow[t]{12}{*}{ Lung cancer } & This review & Japan & 39 & $3.59(3.25-3.96)$ \\
\hline & Lee et al. $2012^{4}$ & N America & 84 & $11.68(10.61-12.85)$ \\
\hline & & UK & 25 & 7.53 (5.40-10.50) \\
\hline & & Scandinavia & 21 & $8.68(7.14-10.54)$ \\
\hline & & Other Europe & 23 & 8.65 (5.98-12.51) \\
\hline & & China & 5 & $2.94(2.23-3.88)$ \\
\hline & & Japan & 18 & $3.55(3.05-4.14)$ \\
\hline & & Other Asia & 7 & $2.90(2.04-4.13)$ \\
\hline & Wakai et al. 2006² & Japan & 23 & $3.64(3.34-3.97)^{a}$ \\
\hline & Nakamura et al. $2009^{6}$ & Asia & NA & $3.54(3.00-4.17)$ \\
\hline & Huxley et al. $2007^{58}$ & Asia & NA & $2.46(2.00-3.04)^{a}$ \\
\hline & & Australia/NZ & NA & $12.55(8.47-18.60)^{a}$ \\
\hline \multirow[t]{6}{*}{ COPD } & This review & Japan & 10 & $3.57(2.72-4.70)$ \\
\hline & & (omitting outliers) & 8 & $3.10(2.57-3.75)$ \\
\hline & Forey et al. $2011^{7}$ & N America & 39 & $4.56(3.69-5.62)$ \\
\hline & & Europe & 55 & $3.31(2.80-3.92)$ \\
\hline & & Asia & 17 & $2.86(2.27-3.60)$ \\
\hline & Nakamura et al. ${ }^{6}$ & Asia & NA & $1.40(1.18-1.66)$ \\
\hline \multirow[t]{8}{*}{ IHD } & This review & Japan & 20 & $2.21(1.96-2.50)$ \\
\hline & Lee et al. $2017^{8}$ & N America & 61 & $1.94(1.77-2.12)$ \\
\hline & & W Europe & 4 & $2.24(1.49-3.39)$ \\
\hline & & Scandinavia & 10 & $2.46(1.85-3.37)$ \\
\hline & & Japan & 9 & $2.21(1.85-2.65)$ \\
\hline & & Other Asia & 8 & $2.15(1.56-2.96)$ \\
\hline & Nakamura et al. $2009^{6}$ & Asia & NA & $1.97(1.66-2.23)$ \\
\hline & $\begin{array}{l}\text { Asia Pacific Cohort } \\
\text { Studies Collaboration }\end{array}$ & Asia & NA & $1.75(1.60-1.90)$ \\
\hline \multirow[t]{9}{*}{ Stroke } & This review & Japan & 16 & $1.40(1.25-1.57)$ \\
\hline & Lee et al. $2017^{8}$ & N America & 33 & $1.50(1.31-1.71)$ \\
\hline & & W Europe & 4 & $1.49(1.18-1.89)$ \\
\hline & & Scandinavia & 2 & $2.72(1.82-4.07)$ \\
\hline & & Japan & 9 & $1.37(1.19-1.58)$ \\
\hline & & Other Asia & 9 & $1.33(1.18-1.51)$ \\
\hline & Nakamura et al. $2009^{6}$ & Asia & NA & $1.34(1.21-1.48)$ \\
\hline & $\begin{array}{l}\text { Asia Pacific Cohort } \\
\text { Studies Collaboration }\end{array}$ & Asia & NA & $1.43(1.32-1.54)$ \\
\hline & Wang et al. $2008^{60}$ & China & NA & $1.22(1.08-1.37)$ \\
\hline
\end{tabular}

astimated from data for sexes separately 
Evidence of international variation in current smoking RRs is much clearer for lung cancer, where the meta-analysis RRs reported for Japan and other Asian countries range from 2.46 to 3.64, while those for North America, Europe and Australia/New Zealand are substantially higher, ranging from 7.53 to 12.55 . The explanation for this difference has been discussed in a number of previous publications (e.g.1-3,35) without any clear explanation being offered. An international case-control study involving populations in the USA and $\operatorname{Japan}^{3}$ found no substantial international differences in average daily consumption or mean duration of smoking, but noted that US cases began smoking 2.5 years earlier than Japanese cases. They suggested that possible explanations for the higher smoking risk in the US study may "include a more toxic cigarette formulation of American manufactured cigarettes as evidenced by higher concentrations of tobacco-specific nitrosamines in both tobacco and mainstream smoke, the much wider use of activated charcoal in the filters of Japanese than in American cigarettes, as well as documented differences in genetic susceptibility and lifestyle factors other than smoking." Other authors ${ }^{1,2,35}$ have referred to the severe shortage of cigarettes in Japan during and shortly after World War II, the higher incidence of lung cancer in nonsmokers in Japan due to indoor air pollutants (including environmental tobacco smoke), the low fat intake and high intake of several phytochemicals in the Japanese diet, and the lower indoor radon concentrations in Japan than in the USA.

Whether lung cancer risk in nonsmokers in Japan is higher than in Western countries is in any case open to question. A recent publication $^{61}$ that indirectly estimated absolute lung cancer mortality rates by smoking status based on a systematic review, found that they were quite similar in Japan to those in most Western countries. For age 70-74 years, mortality rates (per 100,000 per year) in those who had never smoked were estimated as 42.5 (95\% CI 34.5-52.4) in Japan based on $n=14$ estimates, as compared, for example, to $37.6(32.6-43.3, \mathrm{n}=54)$ for the USA, $61.5(46.8-80.8, \mathrm{n}=26)$ for the UK, $29.6(21.9-40.0$, $\mathrm{n}=20)$ for Scandinavia, $38.2(29.3-49.8, \mathrm{n}=31)$ in other countries in Western Europe, and $32.3(22.3-46.8, \mathrm{n}=11)$ for Eastern Europe. It was China, not Japan, that had a markedly higher lung cancer rate of $99.1(90.2-108.8, \mathrm{n}=38)$ in never smokers.

One potential explanation for the difference in the relative risk of lung cancer between Asian and Western populations may lie in differences in the accuracy of reporting smoking habits. We are currently involved in a separate project to review accuracy of reporting smoking habits, using cotinine to validate self-reported smoking habits. We are aware of five studies in Asian populations, three in $\operatorname{Japan}^{62-64}$, one in Korea ${ }^{65}$ and one of South-East Asians resident in the $\mathrm{USA}^{66}$, which report results separately for never, ex and current smokers and by sex. All five give results for women, and four do so for men, and the proportion of true current smokers in self-reported never or ex-smokers (as judged by high cotinine levels) in women (range $12.3 \%$ to $61.6 \%$, overall $45.8 \%$ ) is much higher than it is men (range $0.4 \%$ to $6.0 \%$, overall $3.4 \%$ ). The proportion is also much higher than in 13 data sets (five in males, five in females, three in sexes combined) reported in six publications ${ }^{67-72}$ describing studies in Western populations (England, Finland, Germany, USA) involving large numbers (>2000) of subjects. Here percentages range from $0.4 \%$ to $6.1 \%$, with the overall estimates $1.6 \%$ for males, $3.2 \%$ for females, and $2.3 \%$ for the whole sample.

Although the difference is impressive, the percentage that affects the relative risk for current versus never smokers is the proportion of the current smokers in self-reported never smokers. Here the overall percentages are $7.8 \%$ in Asian females, 5.5\% in Asian males, $1.4 \%$ in Western females and $2.3 \%$ in Western males. If one assumes that the true RR for current smoking and lung cancer is $\mathrm{X}$, the observed $\mathrm{RR}$ based on self-reported data will be $\mathrm{X} /(1+(\mathrm{X}-1) \mathrm{p})$ where $\mathrm{p}$ is the proportion of true current smokers among self-reported never smokers. Thus if $X=10$, the observed RRs would be 5.9 in Asian females, 6.7 in Asian males, 8.9 in Western females and 8.3 in Western males, based on the data sets investigated. Although there are difficulties in interpreting these results for various reasons, including between-study variation in the body fluids and cut-offs used to determine true smokers, and the possibility that self-reported never smokers who are considered to be current smokers may smoke less than current smokers who admit smoking, we feel that these results suggest that different levels of misclassification of smoking habits between Asian and Western populations may contribute to the lower observed current smoker RRs in Asian populations.

\section{Passive smoking}

This review is concerned with the effects of active smoking in Japan on the four diseases concerned. Recent reviews by ourselves $^{73-76}$ and others ${ }^{77}$ have found that evidence in Japan on passive smoking is very sparse, except for lung cancer. For IHD, our recent review ${ }^{75}$ cites only the Hirayama study ${ }^{78}$ as reporting a non-significant relative risk of 1.16 (95\% CI 0.94-1.43), while our review of passive smoking and stroke ${ }^{74}$ cites the Hirayama study as finding "no significant trend" and a study by Nishino et $a l^{79}$ as giving a relative risk of $0.75(0.80-1.12)$. Our review of passive smoking and $\mathrm{COPD}^{76}$ again cited only the relative risk from the Hirayama study of $1.38(0.86-2.21)$, though one very recently published study by Ukawa et $a l^{80}$ did report significantly increased RRs of $2.40(1.39-4.15)$ and $2.88(1.68-4.93)$ for passive smoking at home for $\leq 4$ days per week and almost every day, as compared to none.

For lung cancer, the evidence is much more extensive and two recent reviews $\mathrm{s}^{7377}$ reported very similar overall relative risks for spousal or at home smoking of $1.26(1.11-1.45)$ and $1.28(1.10-1.48)$ based on 13 or 12 individual estimates, although our review ${ }^{73}$ suggested that most, if not all, of the ETS/lung cancer association might be explained by inadequate adjustment for potential confounding by diet and education and by bias due to misclassification of some true smokers as nonsmokers. Even were this association a causal result of exposure to passive smoking it could not explain the substantial difference in active smoking RRs between Asian and Western populations. Not only do the RRs for passive smoking not vary significantly by location ${ }^{73}$, but even if passive smoking exposure were particularly common in Japanese non- 
smokers, the relatively weak association of passive smoking with lung cancer risk could not possibly explain why active smoking relative risks are two-fold or more higher in Western than in Asian populations.

\section{Conclusions}

In Japanese studies, smoking is related to an increased risk of all four diseases studied, though the increase is relatively weak for stroke, and the evidence is limited for COPD. For IHD, the estimated RR for current smoking, of 2.21 (95\%CI 1.96-2.50) is similar to that reported in other Asian and in Western populations and is dose-related, increasing with amount smoked and reducing with years quit. For lung cancer, the estimated RR for current smoking of 3.59 (3.25-3.96), which is also clearly dose-related, is similar to that in other Asian populations but substantially less than in Western populations. The explanation of this difference is unclear but high rates of denial of cigarette smoking may contribute.

\section{Data availability}

All data underlying the results are available as part of the article and no additional source data are required.

\section{Author information}

PNL decided on the methodology, checked the literature searches, studied the derivation of the relative risks, carried out the metaanalyses for IHD and stroke, checked the meta-analyses for lung cancer and COPD, and drafted the manuscript. KJC carried out the literature searches and derived the relative risks and checked the meta-analyses for IHD and stroke. AJT derived the relative risks for lung cancer and COPD. BAF carried out the meta-analyses for lung cancer and COPD, and provided detailed comments on early drafts of the paper. All authors read and approved the final manuscript.

\section{Competing interests}

P N Lee Statistics and Computing Ltd, for whom PNL and KJC are directors, and BAF and AJT are consultants, have for many years carried out work for many different tobacco companies and organizations, including Philip Morris International, the sponsors of this study. The work described here has been carried out independently of the sponsors.

\section{Grant information}

Funding was provided by Philip Morris International. The only role they had in the design of the study and collection, analysis, and interpretation of data was to suggest that the review should be conducted and to provide a brief comment on a near final draft of the paper, suggesting only that we refer to our recent publication on indirectly estimated lung cancer rates by smoking status, reference 61 of the submitted paper.

The funders had no role in study design, data collection and analysis, decision to publish, or preparation of the manuscript.

\section{Acknowledgements}

We thank Dr John Fry for statistical advice, and Yvonne Cooper and Diana Morris for assistance in preparing the various drafts of this publication. We also thank the sponsors for their financial support.

\section{Supplementary material}

Supplementary File 1: Completed PRISMA checklist.

Click here to access the data.

Supplementary File 2: Searches conducted. This document gives more details on the searches conducted.

Click here to access the data.

Supplementary File 3: Relative risks by amount smoked and duration of quitting.

Click here to access the data.

Supplementary File 4: More detailed meta-analysis results for cardiovascular disease and lung cancer.

Click here to access the data.

1. Sobue $\mathrm{T}$, Yamamoto $\mathrm{S}$, Hara M, et al:: Cigarette smoking and subsequent risk of lung cancer by histologic type in middle-aged Japanese men and women: the JPHC study. Int J Cancer. 2002; 99(2): 245-251. PubMed Abstract | Publisher Full Text
2.

Wakai $\mathrm{K}$, Inoue M, Mizoue T, et al.: Tobacco smoking and lung cancer risk: an evaluation based on a systematic review of epidemiological evidence among the Japanese population. Jpn J Clin Oncol. 2006; 36(5): 309-324. PubMed Abstract | Publisher Full Text 
3. Stellman SD, Takezaki T, Wang L, et al.: Smoking and lung cancer risk in American and Japanese men: an international case-control study. Cancer Epidemiol Biomarkers Prev. 2001; 10(11): 1193-1199. PubMed Abstract

4. Lee PN, Forey BA, Coombs KJ: Systematic review with meta-analysis of the epidemiological evidence in the 1900 s relating smoking to lung cancer. $B M C$ Cancer. 2012; 12: 385.

PubMed Abstract | Publisher Full Text | Free Full Text

5. International Agency for Research on Cancer: Tobacco smoking. IARC Monogr Eval Carcinog Risk Chem Hum Lyon, France: IARC; 1986; 38: 421 Reference Source

6. Nakamura K, Huxley R, Ansary-Moghaddam A, et al:: The hazards and benefits associated with smoking and smoking cessation in Asia: a meta-analysis of prospective studies. Tob Control. 2009; 18(5): 345-353. PubMed Abstract | Publisher Full Text

7. Forey BA, Thornton AJ, Lee PN: Systematic review with meta-analysis of the epidemiological evidence relating smoking to COPD, chronic bronchitis and emphysema. BMC Pulm Med. 2011; 11: 36.

PubMed Abstract | Publisher Full Text | Free Full Text

8. Lee PN, Fry JS, Hamling JF, et al.: Estimating the effect of differing assumptions on the population health impact of introducing a Reduced Risk Tobacco Product in the USA. Regul Toxicol Pharmacol. 2017; 88: 192-213. PubMed Abstract | Publisher Full Text

9. Liberati A, Altman DG, Tetzlaff J, et al.: The PRISMA statement for reporting systematic reviews and meta-analyses of studies that evaluate healthcare interventions: explanation and elaboration. BMJ. 2009; 339: b2700. PubMed Abstract | Publisher Full Text | Free Full Text

10. Lee PN, Fry JS, Hamling JS: Using the negative exponential distribution to quantitatively review the evidence on how rapidly the excess risk of ischaemic heart disease declines following quitting smoking. Regul Toxicol Pharmacol. 2012; 64(1): 51-67.

PubMed Abstract | Publisher Full Text

11. Fry JS, Lee PN, Forey BA, et al.: How rapidly does the excess risk of lung cancer decline following quitting smoking? A quantitative review using the negative exponential model. Regul Toxicol Pharmacol. 2013; 67(1): 13-26. PubMed Abstract | Publisher Full Text

12. Lee PN, Fry JS, Thornton A: Estimating the decline in excess risk of cerebrovascular disease following quitting smoking--a systematic review based on the negative exponential model. Regul Toxicol Pharmacol. 2014; 68(1): 85-95.

PubMed Abstract | Publisher Full Text

13. Lee PN, Fry JS, Forey BA: Estimating the decline in excess risk of chronic obstructive pulmonary disease following quitting smoking - a systematic review based on the negative exponential model. Regul Toxicol Pharmacol. 2014; 68: 231-239

PubMed Abstract | Publisher Full Text

14. Fleiss JL, Gross AJ: Meta-analysis in epidemiology, with special reference to studies of the association between exposure to environmental tobacco smoke and lung cancer: a critique. J Clin Epidemiol. 1991; 44(2): 127-139. PubMed Abstract | Publisher Full Text

15. Higgins JP, Thompson SG, Deeks JJ, et al.: Measuring inconsistency in metaanalyses. BMJ. 2003; 327(7414): 557-560.

PubMed Abstract | Publisher Full Text | Free Full Text

16. Egger M, Davey Smith G, Schneider M, et al:: Bias in meta-analysis detected by a simple, graphical test. BMJ. 1997; 315(7109): 629-634. PubMed Abstract | Publisher Full Text | Free Full Text

17. Hitosugi M: Epidemiological study of lung cancer with special reference to the effect of air pollution and smoking habit. Koshu Eisei In Kenkyu Hokoku. 1968; 17: 237-256.

18. Segi M, Kurihara M, Ishikawa S, et al:: Epidemiological survey on lung cancer and smoking. Lung Cancer. 1979; 19: 157-165.

Publisher Full Text

19. Tsugane $\mathrm{S}$, Watanabe $\mathrm{S}$, Sugimura $\mathrm{H}$, et al:: Smoking, occupation and family history in lung cancer patients under fifty years of age. Jpn J Clin Oncol. 1987; 17(4): 309-317.

PubMed Abstract

20. Sobue T, Suzuki T, Horai T, et al:: Relationship between cigarette smoking and histologic type of lung cancer, with special reference to sex difference. Jpn $J$ Clin Oncol. 1988; 18(1): 3-13.

PubMed Abstract | Publisher Full Text

21. Hirayama T: Life-style and mortality: a large scale census based cohort study in Japan. Contributions to epidemiology and biostatistics Wahrendorf J, editor. Basel, Switzerland: Karger, 1990; 6: 138 Reference Source

22. Yamaguchi N, Kido M, Hoshuyama T, et al.: A case-control study on occupational lung cancer risks in an industrialized city of Japan. Jpn J Cancer Res. 1992 83(2): 134-140.

PubMed Abstract | Publisher Full Text

23. Gao CM, Tajima K, Kuroishi T, et al:: Protective effects of raw vegetables and fruit against lung cancer among smokers and ex-smokers: a case-contro study in the Tokai area of Japan. Jpn J Cancer Res. 1993; 84(6): 594-600. PubMed Abstract | Publisher Full Text

24. Sobue T, Suzuki T, Fujimoto I, et al.: Case-control study for lung cancer and cigarette smoking in Osaka, Japan: comparison with the results from western Europe. Jpn J Cancer Res. 1994; 85(5): 464-473.

PubMed Abstract | Publisher Full Text

25. Kihara M, Noda K, Kihara M: Distribution of GSTM1 null genotype in relation to gender, age and smoking status in Japanese lung cancer patients. Pharmacogenetics. 1995; 5(Spec No): S74-S79.

PubMed Abstract | Publisher Full Text

26. Wakai K, Ohno Y, Genka K, et al.: Smoking habits, local brand cigarettes and lung cancer risk in Okinawa, Japan. J Epidemiol. 1997; 7(2): 99-105. PubMed Abstract | Publisher Full Text

27. Hiraki A, Matsuo K, Hamajima N, et al.: Different risk relations with smoking fo non-small-cell lung cancer: comparison of TP53 and TP73 genotypes. Asian Pac J Cancer Prev. 2003; 4(2): 107-112. PubMed Abstract

28. Kawaminami K, Minowa M, Okayama A, et al.: [An association (population attributable fraction) between smoking habit and mortality from all causes, cancer and lung cancer: NIPPON DATA80, 1980-1999. National Integrated Projects for Prospective Observation of Non-communicable Diseases and its Trend in the Aged]. Nihon Eiseigaku Zasshi. 2003; 57(4): 669-673.

PubMed Abstract | Publisher Full Text

29. Minami $\mathrm{Y}$, Tateno $\mathrm{H}$ : Associations between cigarette smoking and the risk of four leading cancers in Miyagi Prefecture, Japan: a multi-site case-control study. Cancer Sci. 2003; 94(6): 540-547.

PubMed Abstract | Publisher Full Tex

30. Yamagishi K, Iso H, Kitamura A, et al:: Smoking raises the risk of total and ischemic strokes in hypertensive men. Hypertens Res. 2003; 26(3): 209-217. PubMed Abstract | Publisher Full Text

31. Fukuchi $Y$, Nishimura M, Ichinose $M$, et al:: COPD in Japan: the Nippon COPD Epidemiology study. Respirology. 2004; 9(4): 458-465.

PubMed Abstract | Publisher Full Text

32. Marugame T, Sobue T, Nakayama $\mathrm{T}$, et al.: Filter cigarette smoking and lung cancer risk; a hospital-based case--control study in Japan. Br J Cancer. 2004; 90(3): 646-651.

PubMed Abstract | Publisher Full Text | Free Full Text

33. Ueshima $\mathrm{H}$, Choudhury SR, Okayama $\mathrm{A}$, et al:: Cigarette smoking as a risk factor for stroke death in Japan: NIPPON DATA80. Stroke. 2004; 35(8): 1836-1841. PubMed Abstract | Publisher Full Text

34. Kanashiki M, Sairenchi T, Saito $\mathrm{Y}$, et al:: Body mass index and lung cancer: a case-control study of subjects participating in a mass-screening program. Chest. 2005; 128(3): 1490-1496.

PubMed Abstract | Publisher Full Text

35. Marugame $\mathrm{T}$, Sobue $\mathrm{T}$, Satoh $\mathrm{H}$, et al:: Lung cancer death rates by smoking status: comparison of the Three-Prefecture Cohort study in Japan to the Cancer Prevention Study II in the USA. Cancer Sci. 2005; 96(2): 120-126. PubMed Abstract | Publisher Full Text

36. Tsushima K, Sone S, Yoshikawa S, et al.: Clinical differences in the Global Initiative for Chronic Obstructive Lung Disease Stage 0. Respir Med. 2006; 100(8): 1360-1367.

PubMed Abstract | Publisher Full Text

37. Ozasa K: Smoking and mortality in the Japan Collaborative Cohort Study for Evaluation of Cancer (JACC). Asian Pac J Cancer Prev. 2007; 8(Suppl): 89-96. PubMed Abstract

38. Kojima S, Sakakibara $\mathrm{H}$, Motani S, et al.: Incidence of chronic obstructive pulmonary disease, and the relationship between age and smoking in a Japanese population. J Epidemiol. 2007; 17(2): 54-60.

PubMed Abstract | Publisher Full Text

39. Osaki Y, Okamoto M, Kaetsu A, et al.: Retrospective cohort study of smoking and lung cancer incidence in rural prefecture, Japan. Environ Health Prev Med. 2007; 12(4): 178-182.

PubMed Abstract | Publisher Full Text | Free Full Text

40. Hirayama F, Lee AH, Binns CW, et al:: Soy consumption and risk of COPD and respiratory symptoms: a case-control study in Japan. Respir Res. 2009; 10: 56. PubMed Abstract | Publisher Full Text | Free Full Text

41. Wakai K, Marugame T, Kuriyama S, et al.: Decrease in risk of lung cancer death in Japanese men after smoking cessation by age at quitting: pooled analysis of three large-scale cohort studies. Cancer Sci. 2007; 98(4): 584-589. PubMed Abstract | Publisher Full Text

42. Honjo $\mathrm{K}$, Iso $\mathrm{H}$, Tsugane $\mathrm{S}$, et al:: The effects of smoking and smoking cessation on mortality from cardiovascular disease among Japanese: pooled analysis of three large-scale cohort studies in Japan. Tob Control. 2010; 19(1): 50-57. PubMed Abstract | Publisher Full Text

43. Kiyohara C, Horiuchi T, Takayama K, et al.: IL1B rs1143634 polymorphism, cigarette smoking, alcohol use, and lung cancer risk in a Japanese population. $J$ Thorac Oncol. 2010; 5(3): 299-304.

PubMed Abstract | Publisher Full Text

44. Osaka D, Shibata $Y$, Abe S, et al.: Relationship between habit of cigarette smoking and airflow limitation in healthy Japanese individuals: the Takahata study. Intern Med. 2010; 49(15): 1489-99.

PubMed Abstract | Publisher Full Tex

45. Shimazu T, Inoue M, Sasazuki S, et al:: Isoflavone intake and risk of lung cancer: a prospective cohort study in Japan. Am J Clin Nutr. 2010; 91(3): 722-728. PubMed Abstract | Publisher Full Text

46. Kondo T, Osugi S, Shimokata K, et al:: Smoking and smoking cessation in 
relation to all-cause mortality and cardiovascular events in 25,464 healthy male Japanese workers. Circ J. 2011; 75(12): 2885-2892.

PubMed Abstract | Publisher Full Text

47. Omori $\mathrm{H}$, Nagano $\mathrm{M}$, Funakoshi $\mathrm{Y}$, et al.: Twelve-year cumulative incidence of airflow obstruction among Japanese males. Intern Med. 2011; 50(15): 1537-1544. PubMed Abstract | Publisher Full Text

48. Egawa $\mathrm{H}$, Furukawa $\mathrm{K}$, Preston $\mathrm{D}$, et al.: Radiation and smoking effects on lung cancer incidence by histological types among atomic bomb survivors. Radiat Res. 2012; 178(3): 191-201. PubMed Abstract | Free Full Text

49. Nakamura K, Nakagawa H, Sakurai M, et al:: Influence of smoking combined with another risk factor on the risk of mortality from coronary heart disease and stroke: pooled analysis of 10 Japanese cohort studies. Cerebrovasc Dis. 2012; 33(5): 480-491.

PubMed Abstract | Publisher Full Text

50. Horie M, Noguchi S, Tanaka W, et al.: Relationships among smoking habits, airflow limitations, and metabolic abnormalities in school workers. PLOS One. 2013; 8(11): e81145.

PubMed Abstract | Publisher Full Text | Free Full Text

51. Ito $\mathrm{H}$, Gallus $\mathrm{S}$, Hosono $\mathrm{S}$, et al.: Time to first cigarette and lung cancer risk in Japan. Ann Oncol. 2013; 24(11): 2870-2875.

PubMed Abstract | Publisher Full Text

52. Eshak ES, Iso H, Yamagishi K, et al.: Modification of the excess risk of coronary heart disease due to smoking by seafood/fish intake. Am J Epidemiol. 2014; 179(10): 1173-1181.

PubMed Abstract | Publisher Full Text

53. Fukumoto $\mathrm{K}$, Ito $\mathrm{H}$, Matsuo $\mathrm{K}$, et al.: Cigarette smoke inhalation and risk of lung cancer: a case-control study in a large Japanese population. Eur J Cancer Prev. 2015; 24(3): 195-200.

PubMed Abstract | Publisher Full Text

54. Hatanaka $Y$, Tamakoshi A, Tsushita K: [Risk factors for ischemic heart disease in males in the prime of life: An eight-year follow-up study]. Sangyo Eiseigake Zasshi. 2015; 57(3): 67-76.

PubMed Abstract | Publisher Full Text

55. Matsunaga $\mathrm{M}$, Yatsuya $\mathrm{H}$, Iso $\mathrm{H}$, et al: Similarities and differences between coronary heart disease and stroke in the associations with cardiovascular risk factors: The Japan Collaborative Cohort Study. Atherosclerosis. 2017; 261: 124-130.

PubMed Abstract | Publisher Full Text

56. Akiba S: Analysis of cancer risk related to longitudinal information on smoking habits. Environ Health Perspect. 1994; 102(Suppl 8): 15-9. PubMed Abstract | Publisher Full Text | Free Full Text

57. Forey B, Hamling J, Hamling J, et al:: International Smoking Statistics. A collection of worldwide historical data. Web edition. Sutton, Surrey: P N Lee Statistics and Computing Ltd, 2006-2016. Reference Source

58. Huxley R, Jamrozik K, Lam TH, et al: Impact of smoking and smoking cessation on lung cancer mortality in the Asia-Pacific region. Am J Epidemiol. 2007; 165(11): 1280-1286.

PubMed Abstract | Publisher Full Text

59. Woodward M, Lam TH, Barzi F, et al.: Smoking, quitting, and the risk of cardiovascular disease among women and men in the Asia-Pacific region. Int $J$ Epidemiol. 2005; 34(5): 1036-1045.

PubMed Abstract | Publisher Full Text

60. Wang J, Ye DQ, Wang K: [Meta-analysis on the stroke with overweight or obesity, smoking and alcohol drinking in Chinese residents]. Zhonghua $Y_{u}$ Fang Yi Xue Za Zhi. 2008; 42(2): 115-118. PubMed Abstract | Publisher Full Text

61. Lee PN, Forey BA: Indirectly estimated absolute lung cancer mortality rates by smoking status and histological type based on a systematic review. $B M C$ Cancer. 2013; 13: 189.

PubMed Abstract | Publisher Full Text | Free Full Text

62. Akiyama $\mathrm{Y}$, Ohkawa $\mathrm{Y}$, Matsuki $\mathrm{H}$, et al:: Misclassification of smoking status: comparison of questionnaire data and urinary cotinine analysis. In: Leslie GB, Leslie KJ, Huang J and Qin Y, editors. Indoor air quality in Asia. Proceedings of the Second international conference on indoor air quality in Asia; 18-20 October 1994; Beijing. Rothenfluh, Switzerland: Indoor Air International: 1994; 319-323.

63. Lee PN: "Marriage to a smoker" may not be a valid marker of exposure in studies relating environmental tobacco smoke to risk of lung cancer in
Japanese non-smoking women. Int Arch Occup Environ Health. 1995; 67(5): 287-294.

PubMed Abstract | Publisher Full Text

64. Tsutsumi A, Kagawa J, Yamano Y, et al.: Relation between cotinine in the urine and indices based on self-declared smoking habits. Environ Health Prev Med. 2002; 6(4): 240-7.

PubMed Abstract | Publisher Full Text | Free Full Text

65. Jung-Choi $\mathrm{KH}$, Khang $\mathrm{YH}$, Cho HJ: Hidden female smokers in Asia: a comparison of self-reported with cotinine-verified smoking prevalence rates in representative national data from an Asian population. Tob Control. 2012; 21(6): 536-542.

PubMed Abstract | Publisher Full Text

66. Wewers ME, Dhatt RK, Moeschberger ML, et al:: Misclassification of smoking status among Southeast Asian adult immigrants. Am J Respir Crit Care Med. 1995; 152 (6 Pt 1): 1917-1921.

PubMed Abstract | Publisher Full Text

67. Office of Population Censuses and Surveys: Health survey for England 1993. Series HS no. 3. Vol London: HMSO, 1995; 498.

68. Jarvis MJ, Feyerabend C, Bryant A, et al:: Passive smoking in the home: plasma cotinine concentrations in non-smokers with smoking partners. Tob Control. 2001; 10(4): 368-374.

PubMed Abstract | Publisher Full Text | Free Full Text

69. Vartiainen E, Seppälä T, Lillsunde $\mathrm{P}$, et al:: Validation of self reported smoking by serum cotinine measurement in a community-based study. J Epidemiol Community Health. 2002; 56(3): 167-170.

PubMed Abstract | Publisher Full Text | Free Full Text

70. Wagenknecht LE, Burke GL, Perkins LL, et al.: Misclassification of smoking status in the CARDIA study: a comparison of self-report with serum cotinine levels. Am J Public Health. 1992; 82(1): 33-36. PubMed Abstract | Publisher Full Text | Free Full Text

71. Wallner-Liebmann SJ, Grammer TB, Siekmeier R, et al.: Smoking denial in cardiovascular disease studies. Adv Exp Med Biol. 2013; 788: 35-38. PubMed Abstract | Publisher Full Text

72. Heller WD, Sennewald E, Gostomzyk JG, et al.: Validation of ETS exposure in a representative population in Southern Germany. Proceedings of the Proceedings of Indoor Air '93; 4-8 July 1993; Helsinki. 1993; 3: 361-365.

73. Lee PN, Fry JS, Forey B, et al:: Environmental tobacco smoke exposure and lung cancer: a systematic review. World J Metaanal. 2016; 4: 10-43. Publisher Full Text

74. Lee PN, Thornton AJ, Forey BA, et al:: Environmental Tobacco Smoke Exposure and Risk of Stroke in Never Smokers: An Updated Review with Meta-Analysis. J Stroke Cerebrovasc Dis. 2017; 26: 204-216. PubMed Abstract | Publisher Full Text

75. Lee PN, Forey BA, Hamling JS, et al.: Environmental tobacco smoke exposure and heart disease: A systematic review. World J Metaanal. 2017; 5(2): 14-40. Publisher Full Text

76. Lee PN, Forey BA, Coombs KJ, et al.: Epidemiological evidence relating environmental smoke to COPD in lifelong non-smokers: a systematic review [version 1; referees: awaiting peer review]. F1000Research. 2018; 146. Publisher Full Text

77. Hori M, Tanaka H, Wakai K, et al:: Secondhand smoke exposure and risk of lung cancer in Japan: a systematic review and meta-analysis of epidemiologic studies. Jpn J Clin Oncol. 2016; 46(10): 942-951. PubMed Abstract | Publisher Full Text | Free Full Text

78. Hirayama T: Lung cancer in Japan: effects of nutrition and passive smoking. In: Mizell M and Correa P, editors. Lung cancer: causes and prevention. Proceedings of the International Lung Cancer Update Conference; March 3-5, 1983; New Orleans, Louisiana. Deerfield Beach, Florida: Verlag Chemie International, Inc, 1984; 175-195. Data clarifications appear in Passive smoking [Letter]. N Z Med J. 1990; 103(883): 54

PubMed Abstract

79. Nishino $\mathrm{Y}$, Minami $\mathrm{Y}$, Kawai $\mathrm{M}$, et al:: Cigarette smoking and breast cancer risk in relation to joint estrogen and progesterone receptor status: a case-control study in Japan. Springerplus. 2014; 3: 65 .

PubMed Abstract | Publisher Full Text | Free Full Text

80. Ukawa S, Tamakoshi A, Yatsuya $\mathrm{H}$, et al.: Passive smoking and chronic obstructive pulmonary disease mortality: findings from the Japan collaborative cohort study. Int J Public Health. 2017; 62(4): 489-494. PubMed Abstract | Publisher Full Text 


\section{Open Peer Review}

\section{Current Peer Review Status:}

\section{Version 1}

Reviewer Report 06 February 2019

https://doi.org/10.5256/f1000research.15218.r38476

(C) 2019 Heller $\mathbf{W}$. This is an open access peer review report distributed under the terms of the Creative Commons Attribution License, which permits unrestricted use, distribution, and reproduction in any medium, provided the original work is properly cited.

Wolf-Dieter Heller

Institute of Economics, Econometrics and Statistics, Karlsruhe Institute of Technology, Karlsruhe, Germany

The authors report the results of meta-analyses based on studies in Japan relating cigarette smoking to the risk of the four major smoking-related diseases. Data are summarized for current and former smokers and in relation to amount smoked and time quit. The relative risks reported for Japan are compared with those for other Asian and Western studies reported in published meta-analyses.

The results shown are mostly quite similar to those reported elsewhere, with relative risks for current smoking elevated for all four diseases, relative risks for former smoking somewhat lower, and evidence of a dose response with increasing amount smoked and decreasing time quit. While current smoking relative risks for heart disease and stroke for Japan are similar to those in other countries, it is notable that, for lung cancer, the relative risks for Japan are much lower than seen in Western countries, though similar to those seen in other Asian countries. The paper includes an interesting discussion about the reasons why this might be so.

Generally, the paper is very well structured and clearly written, and the material presented provides considerable reassurance about the completeness of the searches and the accuracy of the meta-analysis results presented. Over the last decades Peter Lee and his co-authors have published a broad range of papers dealing with the risk of smoking in general. Monitoring these publications over many years I was always impressed how clearly the papers are written, especially the MA ones.

The results of the present publication are convincing, clear and concise. Concerning the lung cancer results this paper again points towards an important aspect in public health which definitely needs further research: the substantially lower RR in Japan compared to western countries.

Are the rationale for, and objectives of, the Systematic Review clearly stated? 
Yes

Are sufficient details of the methods and analysis provided to allow replication by others? Yes

Is the statistical analysis and its interpretation appropriate?

Yes

Are the conclusions drawn adequately supported by the results presented in the review? Yes

Competing Interests: No competing interests were disclosed.

Reviewer Expertise: Statistics, Epidemiology

I confirm that I have read this submission and believe that I have an appropriate level of expertise to confirm that it is of an acceptable scientific standard.

Author Response 06 Feb 2019

Peter Lee, P.N. Lee Statistics and Computing Ltd., Sutton, UK

I thank Dr Heller for his kind comments and the time he spent on the review.

Competing Interests: No competing interests were disclosed.

Reviewer Report 16 March 2018

https://doi.org/10.5256/f1000research.15218.r31116

(c) 2018 Muscat J. This is an open access peer review report distributed under the terms of the Creative Commons Attribution License, which permits unrestricted use, distribution, and reproduction in any medium, provided the original work is properly cited.

\section{Joshua E. Muscat}

Department of Public Health Sciences, Penn State Tobacco Center of Regulatory Science, Penn State Health Milton S. Hershey Medical Center, Hershey, PA, USA

These authors have vast experience in MA and the analysis is carefully done and interpreted. The methods conform to appropriate MA methodology.

This is a useful paper as differences in smoking-related risks between Japan and Western countries have important implications with regard to potential cigarette toxicity or risk moderators. The conclusions are quite reasonable.

Are the rationale for, and objectives of, the Systematic Review clearly stated? 
Yes

Are sufficient details of the methods and analysis provided to allow replication by others? Yes

Is the statistical analysis and its interpretation appropriate?

Yes

Are the conclusions drawn adequately supported by the results presented in the review? Yes

Competing Interests: No competing interests were disclosed.

Reviewer Expertise: Epidemiology

I confirm that I have read this submission and believe that I have an appropriate level of expertise to confirm that it is of an acceptable scientific standard.

Author Response 16 Mar 2018

Peter Lee, P.N. Lee Statistics and Computing Ltd., Sutton, UK

I thank Dr Muscat for his kind comments.

Competing Interests: No competing interests were disclosed.

The benefits of publishing with F1000Research:

- Your article is published within days, with no editorial bias

- You can publish traditional articles, null/negative results, case reports, data notes and more

- The peer review process is transparent and collaborative

- Your article is indexed in PubMed after passing peer review

- Dedicated customer support at every stage

For pre-submission enquiries, contact research@f1000.com 